\title{
The Reaction Path of Product Release in NO Detoxification at the Active Site of Truncated Hemoglobin $\mathbf{N}$ in MCSCF Approach
}

\author{
Simon K.V., Tulub A.V.* \\ Saint-Petersburg State University
}

\begin{abstract}
The Multi-Configurational Self-Consistent Field approach with the geometry optimization was applied to the calculation of electronic properties of active site of heme core of truncated hemoglobin N, with the inclusion of [ONOO] functional group and two water molecules. The localized molecular orbitals are employed as a starting set. Two subspaces of full interaction have been used by the construction of MCSCF wavefunction. The first one includes 3d-orbitals of iron atom, and the second contains bonding and antibonding molecular orbitals of peroxynitrite with one unshared electronic pair of the $\mathrm{O}_{2}$ fragment. The reaction is characterized by two transition states; the products are nitrate anion $\mathrm{NO}_{3}^{-}$and one unbound water molecule. There arise an evidence of $\mathrm{NO}_{2}$ and $\mathrm{NO}$ radicals as the reaction products.
\end{abstract}

Key words: tubercle bacillus, heme active center, peroxynitrite structure, MCSCF approach, transition states, reaction path, $\mathrm{O}_{2} / \mathrm{NO}$ chemistry.

\section{INTRODUCTION}

Truncated hemoglobin $\mathrm{N}(\operatorname{trHbN})$, a member of a hemoprotein family, is an integral part of the tubercle bacillus hemoglobin, Mycobacterium tuberculosis. The heme core (heme trHbN) is a ferroprotoporphyrin ring $(\mathrm{FeP})$ with known structure [1]. The immune system attacks the bacillus, M. tuberculosis by transmission of NO radical through a long channel (20 $\AA$ ) and molecule $\mathrm{O}_{2}$ through a short $(8 \AA$ ) channel to the heme core. An active heme site produces the reaction

$$
\mathrm{NO}+\mathrm{O}_{2}+\mathrm{Fe}(\mathrm{II}) \rightarrow \mathrm{NO}_{3}^{-}+\mathrm{Fe}(\mathrm{III})
$$

which is the defense mechanism of $M$. tuberculosis in a latent state. The reaction ends by the removing the nitrate anion $\mathrm{NO}_{3}^{-}$through the third channel with an assistance of two water molecules [2-4]. When the bond length $\mathrm{Fe}-\mathrm{NO}_{3}$ increases, the $\mathrm{NO}_{3}^{-}$diffusion is mostly regulated by interaction with the amino acid fragments GlnE and TyrB, hydrogen bonding to nitrate anion. The interaction of various nitric oxides with the FeP ring was treated in the gas phase experimentally (IR-spectra) and theoretically (DFT approach) in [5, 6].

There arises a great interest in the investigation of the other kinds of the reaction products in complex $\mathrm{NO}+\mathrm{O}_{2}+\mathrm{Fe}$ (II) for finding a way of how M. tuberculosis is recovered from a latent state. This problem was investigated in [7] in a framework of (QM/MM) method combined with a PCM model for a biological cell containing FeP, a large number (131) of amino acids and water molecules. It was demonstrated the appearance in the reaction (1) of $\mathrm{NO}_{2}$ as well as NO radicals.

The reality of the mentioned products needs the investigation of the activation barriers arising on potential energy surface (PES) at an active site of heme trHbN, the description of the reaction path and possible products. To our knowledge, it was not done before. The calculations

*tulub@nk7099.spb.edu 
were performed in Multi-Configurational Self-Consistent Field (MCSCF) approach for the different total spin states, we clarify first the method choice.

\section{THE COMPUTATION PROCEDURE}

Peroxynitrite (ONOO) $)^{-}$represents a weakly bound system in the gas phase, its energy calculation needs a careful determination of the correlation energy, the various versions of multiconfigurational self-consistent field (MCSCF) method were used earlier in treating different spin states of $(\mathrm{ONOO})^{-}[8-10]$. The ground state of $\mathrm{NO}_{3}^{-}$has a symmetry $\mathrm{D}_{3 \mathrm{~h}}$ of a regular triangle, the $(\mathrm{ONOO})^{-} \rightarrow \mathrm{NO}_{3}^{-}$regrouping is unfavorable in the gas phase due to the high activation barriers [8]. The water surroundings stabilize slightly the system, the main role belongs to two water molecules, they are explicitly included into the treated system $(\mathrm{ONOO})+\mathrm{FeP}$. The main role in the FeP ring is due to iron atom, the ground and first exited states of $\mathrm{FeP}$ follows those of the free iron with positive charge $\mathrm{Fe}(\mathrm{II})$, the wave function of $\mathrm{FeP}$ is intended to be an exact eigenfunction of $\mathrm{S}^{2}$ operator. The $4 \mathrm{~s}$-electrons are delocalized in the plain of porphyrin ring forming coordination bonds. The geometry of the anionic (ONOO) structures arising due to the electron charge transfer from Fe(II) in the reaction (1) is close to that of the peroxynitrite in gas phase. The ionization potentials of iron (IP1), (IP2) and (IP3) should to be reproduced carefully enough. We use below the basis set described earlier in our work [9], which gives the reasonable values of the mentioned ionization potentials. The calculations scheme looks as the following: 1) choice of iron atom basis set and calculation of ground and first low-lying excited states of FeP, 2) description of peroxynitrite and nitrate anion structures in molecular complex, 3) determination of the TS in the reaction (1) and 4) investigation of the reaction path on the PES, which lead to $\mathrm{NO}_{3}^{-}$products and, with some assumptions, to $\mathrm{NO}_{2}$ and $\mathrm{NO}$ products. The first two points were discussed earlier in our works $[9,10]$ at MCSCF level, we concentrate below our attention on the points 3) and 4). The calculations were performed by means of GAMESS (2019) program [11], the MCSCF method was employed on the ground of restricted CI expansions [12, 13]. All graphical structures were created by wxMacMolPlt program [14].

\section{THE ELECTRONIC STRUCTURE AND THE GEOMETRY OF THE GROUND STATE}

The whole starting complex includes iron ferroporphyrin $(\mathrm{FeP})$, iron atom bound with imidazole $\left(\mathrm{C}_{3} \mathrm{~N}_{2} \mathrm{H}_{4}\right)$ ring, two water molecules bound to $(\mathrm{ONOO})^{-}$anion, it is represented after the geometry optimization in Figure 1, taken from our previous work [9]. The peroxynitrite structure seems to be caught almost in pincers between two water molecules.

Consider the total spin states for a complex considering $\mathrm{FeP}$ in its ground state with the spin $S=2$. The total spin FeP $+(\mathrm{ONOO})$ radical takes the values $S=5 / 2$ or $S=3 / 2$. According to the Hund rule, the total spin is accepted to be $S=5 / 2$, at least as a starting value, and in the case of dimeric structure of a peroxynitrite [8] the total spin can be set to $S=7 / 2$.

Two subspaces of full interaction (CAS) have been used by the construction of MCSCF wavefunction, the first one includes 3d-orbitals of iron atom and the second contains bonding and antibonding molecular orbitals (MOs) of peroxynitrite with one unshared electronic pair of the $\mathrm{O}_{2}$ fragment $[9,10]$. The both subspaces were united into one $\operatorname{CASSCF}(15,14)$ active space. 


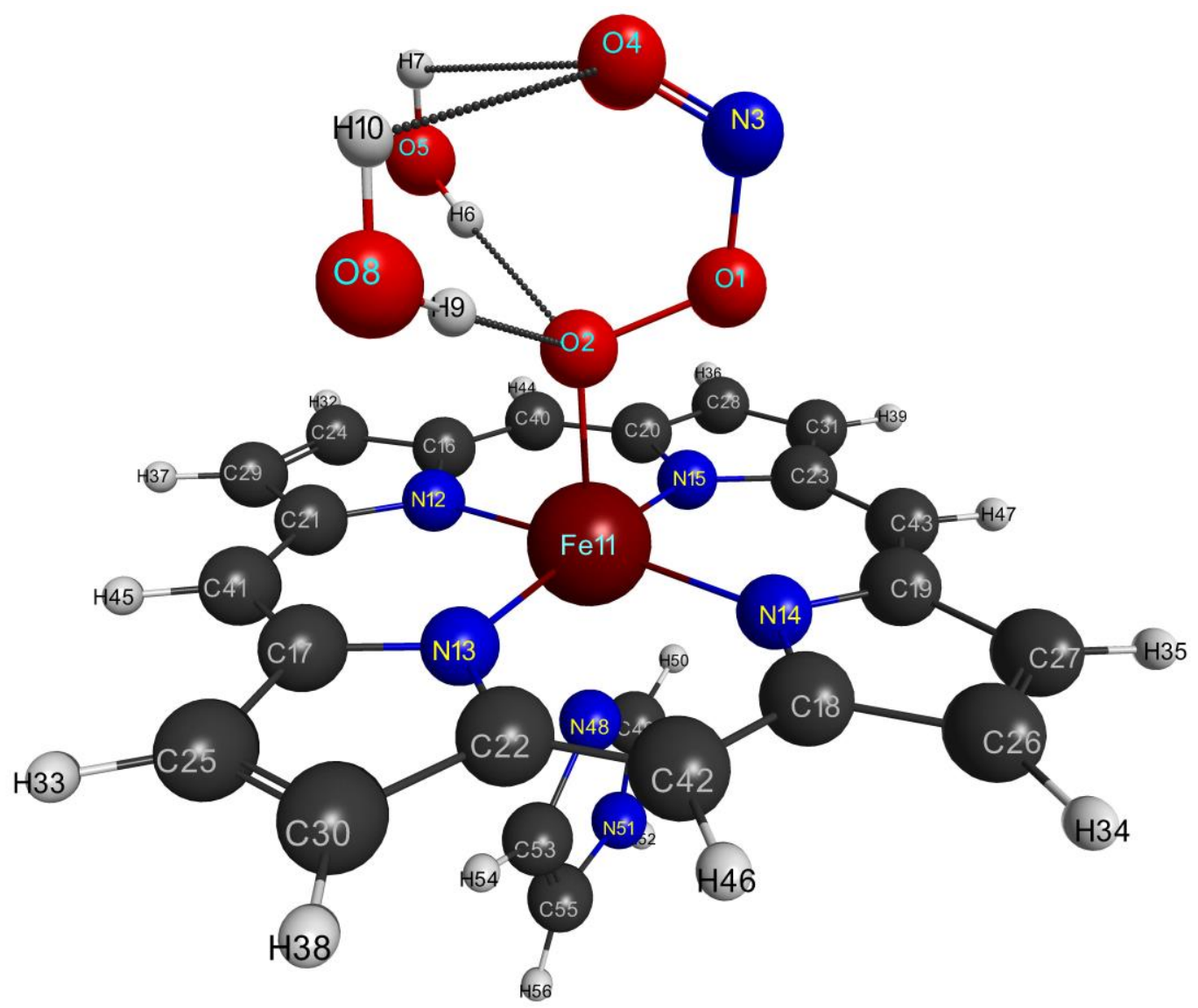

Fig. 1. The ground state optimal geometry of complex $\left[\left(\mathrm{H}_{2} \mathrm{O}\right)_{2} \mathrm{OO}-\mathrm{NO}\right]+\mathrm{Fe}$-porphyrin + imidazole (reagent). $E=-2900.030319$ a.u. $(0 \mathrm{kcal} / \mathrm{mol})$.

\section{TRANSITION AND INTERMEDIATE STRUCTURES}

There were found after an usual procedure the two transition states (TS), separated by intermediate minimum. The reaction $[\mathrm{OO}-\mathrm{NO}]^{-} \rightarrow\left[\mathrm{NO}_{3}\right]^{-}$can be divided into the two steps, the first one is represented as $[\mathrm{OO}-\mathrm{NO}]^{-} \rightarrow[\mathrm{O}]^{-}+\mathrm{NO}_{2}$ and the second as $[\mathrm{O}]^{-}+\mathrm{NO}_{2} \rightarrow\left[\mathrm{NO}_{3}\right]^{-}$. The main geometry change takes place mainly in the group [OO-NO $]^{-}$ and water molecules located near the iron ion, we represent below only the restricted part of the whole structure. The TS1 and the intermediate minimum (IM) geometry are given in Figure 2, the energy change is indicated relative to the ground state.

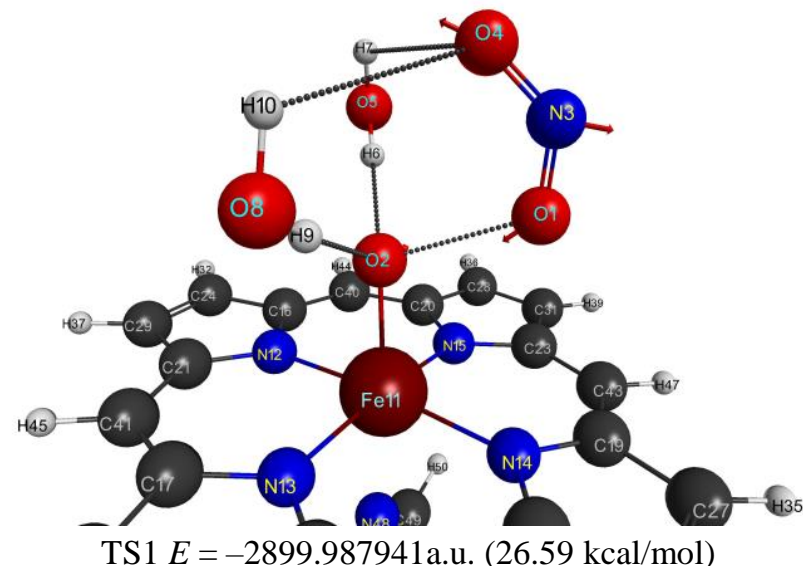

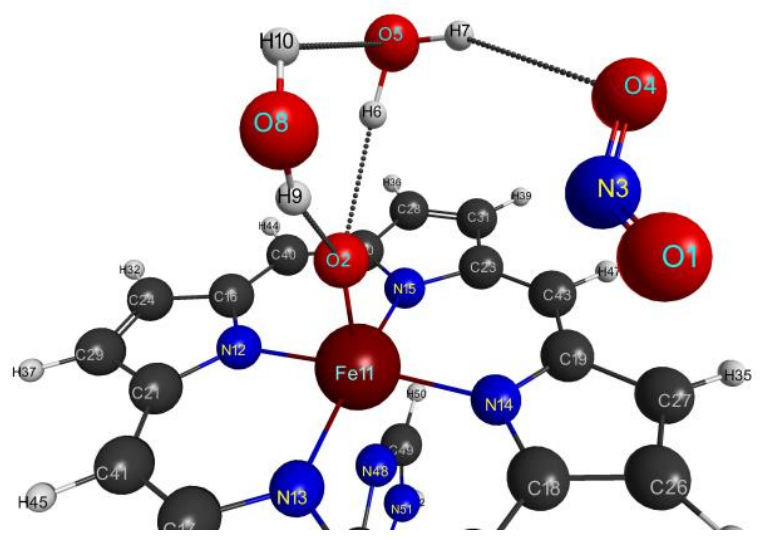

IM $E=-2899.994043$ a.u. $(22.76 \mathrm{kcal} / \mathrm{mol})$

Fig. 2. Transition state 1 (TS1) and intermediate minimum (IM) structures on the reaction path. 
The remarkable feature of the IM geometry consists in departure of $\mathrm{NO}_{2}^{*}$ group from the main structure; it remains connected to it by a hydrogen bond. The radical nature of the $\mathrm{NO}_{2}^{*}$ group can be clearly seen when considering the corresponding natural orbital localized on $\mathrm{NO}_{2}^{*}$ group, it is well separated from all the others (see Figure 3).

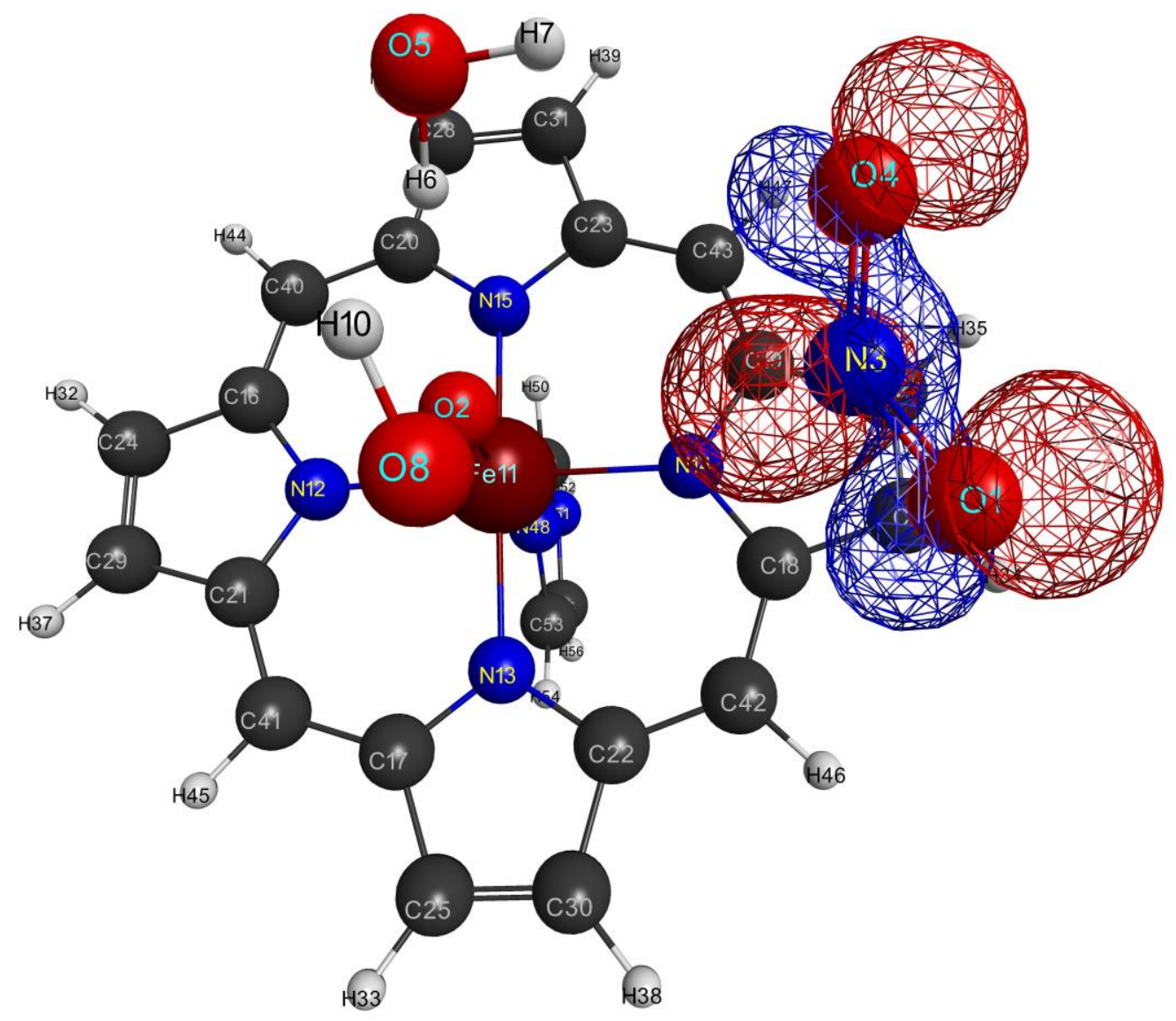

Fig. 3. Singly occupied natural orbital, localized on $\mathrm{NO}_{2}^{*}$ group.

The highest relative energy $26.6 \mathrm{kcal} / \mathrm{mol}$ has the TS1, it can be regarded as an activation energy for the reaction (1). It is considerably smaller than the activation energy $36.2 \mathrm{kcal} / \mathrm{mol}$ in the gas phase of the mentioned regrouping $(\mathrm{ONOO})^{-} \rightarrow \mathrm{NO}_{3}^{-}$[8].

Consider the second TS and product of the reaction (see Figure 4). The second TS2 has a slightly greater energy compared to the IM state, namely $0.173 \mathrm{kcal} / \mathrm{mol}$. It means that PES becomes very flat in the IM point domain. The system moves practically free downward to the product valley containing one unbound and one bound water molecule. The later connects with nitrate anion via one hydrogen bond. The full energy effect is about $-28 \mathrm{kcal} / \mathrm{mol}$ what is much less the value $-51 \mathrm{kcal} / \mathrm{mol}$ in the gas phase [8]. 


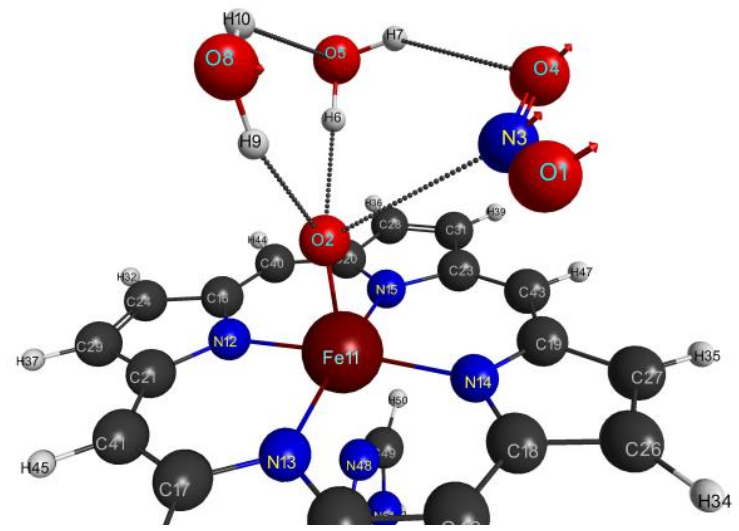

TS2 $E=-2899.993767$ a.u. $(22.94 \mathrm{kcal} / \mathrm{mol})$

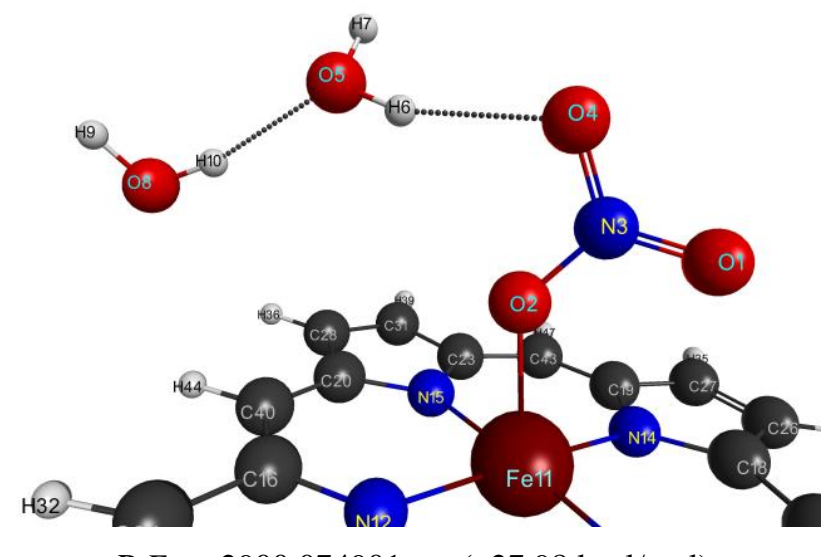

P $E=-2900.074901$ a.u. $(-27.98 \mathrm{kcal} / \mathrm{mol})$

Fig. 4. Transition state $2(\mathrm{TS} 2)$ and product $(\mathrm{P})$ of the reaction.

\section{Reaction path calculation}

The calculated fragments of the reaction path using IRC algorithm is represented in Figure 5. Table 1 contains the detailed information on the essential distances change along the reaction path.
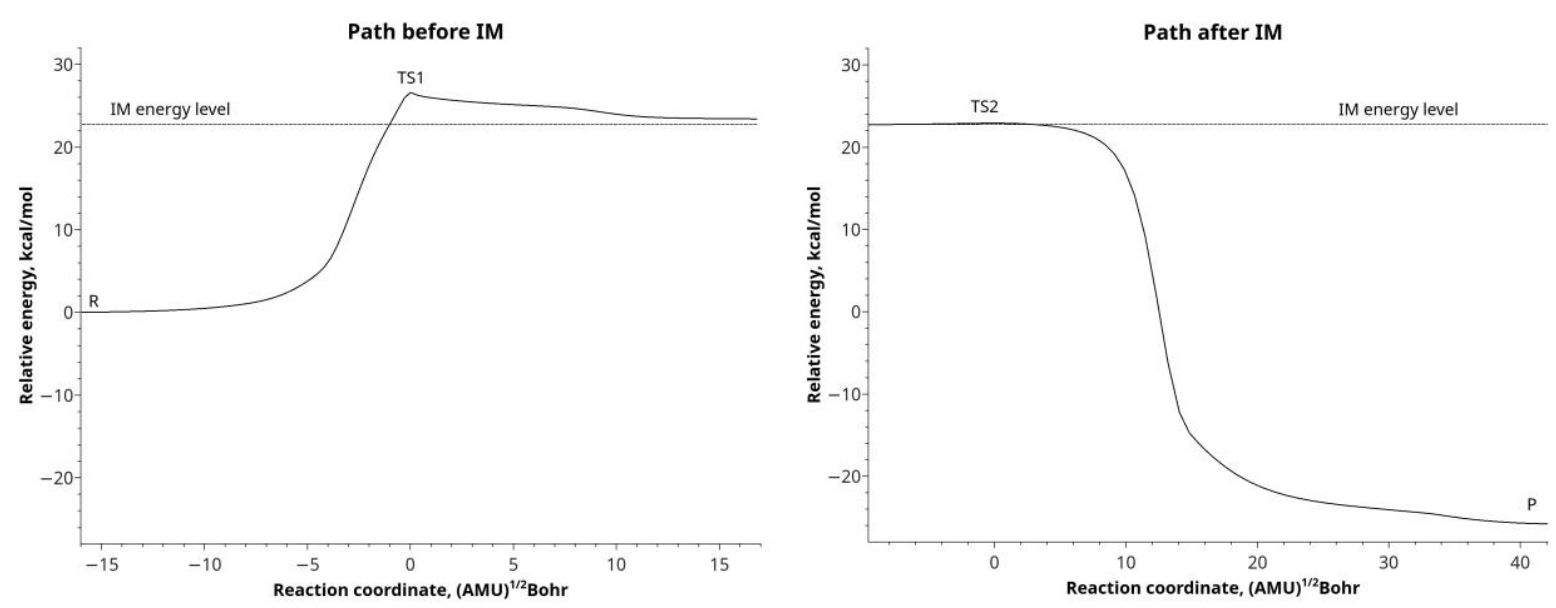

Fig. 5. The reaction path $\left[\left(\mathrm{H}_{2} \mathrm{O}\right)_{2} \mathrm{OO}-\mathrm{NO}\right]^{-} \rightarrow\left[\left(\mathrm{H}_{2} \mathrm{O}\right)_{2} \mathrm{O}\right]^{-}+\mathrm{NO}_{2} \rightarrow\left[\mathrm{H}_{2} \mathrm{ONO}_{3}\right]^{-}+\mathrm{H}_{2} \mathrm{O}$ before and after the intermediate minimum.

We conclude comparing the gas phase reaction and the reaction at the active site of heme $\mathrm{trHbN}$ that the recombination of peroxynitrite into nitrate anion leads to 1) the decrease of an activation barrier, 2) the decrease of the reaction energy effect. The last effect is of importance for the stability of Fe-complex, the peroxynitrite has less destructive effect compared to that in the gas phase. The found activation energy $26.6 \mathrm{kcal} / \mathrm{mol}$ can be of importance for the future nitrate anion motion along the egression pathway.

The important feature or the reaction is the release of one water molecule at the end of the reaction as well as more or less evidence of $\mathrm{NO}_{2}$ release as the reaction product. The geometry of a bound radical $\mathrm{NO}_{2}$, figure 2 , is close to that for a free $\mathrm{NO}_{2}$, it has a noticeable dipole moment. It becomes of importance the electrostatic dipole-dipole interaction of $\mathrm{NO}_{2}$ group with the amino acids fragments in the mentioned cell. 
Table 1. Change of interatomic distances along the reaction path $\left[\left(\mathrm{H}_{2} \mathrm{O}\right)_{2} \mathrm{OO}-\mathrm{NO}\right]^{-} \rightarrow\left[\left(\mathrm{H}_{2} \mathrm{O}\right)_{2} \mathrm{O}\right]^{-}+\mathrm{NO}_{2} \rightarrow\left[\mathrm{H}_{2} \mathrm{ONO}_{3}\right]^{-}+\mathrm{H}_{2} \mathrm{O}$ at the active site of trHbN

\begin{tabular}{|c|c|c|c|c|c|}
\hline $\boldsymbol{r}, \boldsymbol{\AA}$ & Reagent & $\begin{array}{c}\text { Transition } \\
\text { state 1 }\end{array}$ & $\begin{array}{c}\text { Intermediate } \\
\text { minimum }\end{array}$ & $\begin{array}{c}\text { Transition } \\
\text { state 2 }\end{array}$ & Product \\
\hline $\mathrm{r}(\mathrm{O} 1-\mathrm{O} 2)$ & $1.468^{*}$ & $2.186^{*}$ & 4.530 & 3.723 & 2.178 \\
\hline $\mathrm{r}(\mathrm{O} 1-\mathrm{N} 3)$ & $1.340^{*}$ & $1.207^{*}$ & $1.195^{*}$ & $1.194^{*}$ & $1.221^{*}$ \\
\hline $\mathrm{r}(\mathrm{O} 2-\mathrm{N} 3)$ & 2.353 & 2.897 & 3.717 & $3.031^{*}$ & $1.293^{*}$ \\
\hline $\mathrm{r}(\mathrm{N} 3-\mathrm{O} 4)$ & $1.212^{*}$ & $1.197^{*}$ & $1.176^{*}$ & $1.177^{*}$ & $1.229^{*}$ \\
\hline $\mathrm{r}(\mathrm{O} 2-\mathrm{Fe} 11)$ & $2.057^{*}$ & $2.002^{*}$ & $1.952^{*}$ & $1.964^{*}$ & $2.096^{*}$ \\
\hline $\mathrm{r}(\mathrm{O} 2-\mathrm{H} 6)$ & $2.093^{*}$ & $1.981^{*}$ & $1.991^{*}$ & $1.971^{*}$ & 2.627 \\
\hline $\mathrm{r}(\mathrm{O} 2-\mathrm{H} 9)$ & $2.074^{*}$ & $1.963^{*}$ & $2.007^{*}$ & $2.066^{*}$ & 5.732 \\
\hline $\mathrm{r}(\mathrm{O} 4-\mathrm{H} 7)$ & $2.767^{*}$ & $2.849^{*}$ & $2.594^{*}$ & $2.671^{*}$ & 3.097 \\
\hline $\mathrm{r}(\mathrm{O} 4-\mathrm{H} 10)$ & $2.773^{*}$ & $2.883^{*}$ & 3.522 & 3.745 & 4.633 \\
\hline $\mathrm{r}(\mathrm{O} 4-\mathrm{H} 6)$ & 2.698 & 3.029 & 3.510 & 3.245 & $2.012^{*}$ \\
\hline $\mathrm{r}(\mathrm{O} 5-\mathrm{H} 10)$ & 4.412 & 4.604 & $2.705^{*}$ & $2.508^{*}$ & $1.981^{*}$ \\
\hline
\end{tabular}

*chemical bonds

Consider the energy difference of potential energy surface with the spin $S=5 / 2$ from the others PES states for some selected points, we present in the table 2 the data for IM point vicinity. The PES with $S=2.5$ has practically the same energy at IM as the potential energy surface with $S=1.5$, it is reasonable well separated from all the others.

Table 2. The energies for different spin states in the vicinity of IM

\begin{tabular}{|c|c|c|c|}
\hline Total spin & The full energy, a.u. & $\begin{array}{c}\text { Relative energies } \\
\mathbf{k c a l} / \mathbf{m o l}\end{array}$ & The type \\
\hline$S=2.5$ & -2899.99401602 & 22.781 & bound \\
\hline$S=1.5$ & -2899.99400439 & 22.788 & bound \\
\hline$S=3.5$ & -2899.99309619 & 23.358 & unbound \\
\hline$S=0.5$ & -2899.90888384 & 76.202 & excited \\
\hline
\end{tabular}

\section{CONCLUSIONS}

The geometry of a bound radical $\mathrm{NO}_{2}$, shown in Figure 2, is close to that for a free $\mathrm{NO}_{2}$ having a noticeable dipole moment. It becomes of importance the electrostatic dipole-dipole interaction of $\mathrm{NO}_{2}$ group with the amino acids (AA), fragments in the mentioned biological cell. Some number of (AA), depending of the isomer, poses even in the gas phase a large dipole moments. The water environment leads to the AA dipole moment increase, especially by the transition (AA) into a zwitterionic state, due to the proton transfer from the carboxyl COOH group into the amino group $\mathrm{NH}_{2}$. There arises at the end of the process (1) one additional water molecule. The repeating of immune system attack increases the total number of water. It leads in its turn to the AA-dipole moment increase, to the increase of AA interaction energy with the $\mathrm{NO}_{2}$ group and to the probability of this strong oxidant product. That means the end of the latent state of tubercle bacillus infection. 


\title{
REFERENCES
}

1. Milani M., Pesce A., Ouellet Y., Dewilde S., Friedman J., Ascenzi P., Guertin M., Bolognesi M. Journal of Biological Chemistry. 2004. V. 279. № 20. P. 21520-21525. doi: $10.1074 /$ jbc.M401320200.

2. Crespo A., Marti M.A., Kalko S.G., Morreale A., Orozco M., Gelpi J.L., Luque F.J., Estrin D.A. J. Am. Chem. Soc. 2005. V. 127. P. 4433. doi: $10.1021 / j a 0450004$.

3. Bidon-Chanal A., Marti M.A., Estrin D.A., Luque F.J. J. Am. Chem. Soc. 2007. V. 129. P. 6782-6788. doi: $10.1021 /$ ja0689987.

4. Marti M.A., Bidon-Chanal A., Crespo A., Yeh S.-R., Guallar V., Luque F.J., Estrin D.A. J. Am. Chem. Soc. 2008. V. 130. P. 1688. doi: 10.1021/ja076853+.

5. Kurtikyan T.S., Ford P.C. Angew. Chem. Int. 2006. V. 45. P. 492. doi: 10.1002/anie.200502409.

6. Kurtikyan T.S., Hovhannisyan A.A., Hakobian M.E., Patterson J.C., Iretskii A., Ford P.C. J. Am. Chem. Soc. 2007. V. 129. P. 3576.

7. Mishra S., Meuwly M. J. Am. Chem. Soc. 2010. V. 132. P. 2968.

8. Simon K.V., Tulub A.V. Optics and Spectroscopy. 2009. V. 107. P. 46.

9. Simon K.V., Tulub A.V. Mathematical Biology and Bioinformatics. 2011. V. 6. P. 23. doi: $\underline{10.17537 / 2011.6 .23}$.

10. Simon K.V., Tulub A.V. Journal of Structural Chemistry. 2016. V. 57. P. 14.

11. Schmidt M.W., Baldridge K.K., Boatz J.A., Elbert S.T., Gordon M.S., Jensen J.H., Koseki S., Matsunaga N., Nguyen K.A., Su S.J., Windus T.L., Dupuis M., Montgomery J.A. J. Comput. Chem. 1993. V. 14. P. 1347.

12. Panin A.I., Simon K.V. Intern. J. Quant. Chem. 1996. V. 59. P. 471.

13. Ivanic J. Journal of Chemical Physics. 2003. V. 119. P. 9364.

14. Bode B.M., Gordon M.S. J. Mol. Graphics and Modeling. 1998. V. 16. P. 133.

\section{Путь реакции высвобождения продукта при детоксикации NO на активном центре усеченного гемоглобина $\mathbf{N}$ в теории многоконфигурационного самосогласованного поля}

\author{
Симон К.В., Тулуб А.В.
}

\section{Санкт-Петербургский государственный университет. Россия}

\begin{abstract}
Аннотация. Теория мультиконфигурационного самосогласованного поля (МКССП) с оптимизацией геометрии была применена для расчета электронных свойств активного центра гемового ядра усеченного гемоглобина $\mathrm{N}$, в который включена функциональная группа [ONOO] и две молекулы воды. В качестве стартовых были взяты локализованные молекулярные орбитали. Для построения МКССП функций были использованы два подпространства полного взаимодействия. Первое из них включает 3d-функции атома железа, второе - связанные и разрыхляющие орбитали пероксинитрита вместе подобными орбиталями $\mathrm{O}_{2}$-фрагмента. Реакция
\end{abstract}


характеризуется двумя переходными состояниями, ее продуктами является нитратный анион $\left[\mathrm{NO}_{3}\right]^{-}$вместе с одной несвязанной молекулой воды. Показано, что существует вероятность образования в качестве продуктов радикалов $\mathrm{NO}_{2}$ и $\mathrm{NO}$.

Ключевые слова: бацилла туберкулеза, структура активного центра гема, пероксинитритная структура, неэмпирический МКССП расчет, переходные состояния, $\mathrm{O}_{2} / \mathrm{NO}$ химия. 